Fikroh : Jurnal Pemikiran dan Pendidikan Islam

Volume. 12, Number. 2, Juli 2019

p-ISSN : 2087-7501, e-ISSN : 2715-4459

H1m : 149-165

Journal Home Page : https://jurnal.stai-alazharmenganti.ac.id/index.php/fikroh

\title{
PEMIKIRAN GUS DUR TENTANG PENDIDIKAN ISLAM MULTIKULTURAL
}

\author{
Mulyadi \\ STAI Al-Azhar Menganti, Gresik, Indonesia \\ mulyadi091265@gmail.com
}

\begin{abstract}
This study aims to explore Gus Dur's views on multiculturalism and the concept of multicultural Islamic education. This research belongs to the category of library research, because the main data source comes from literature review. The collected data is then analyzed using content analysis techniques with a descriptive approach. Indonesia is a country that consists of various ethnic groups, races, ethnicities, religions, languages. This diversity is a uniqueness that characterizes the Indonesian nation, diversity is sunnatullah, but on one side of the diversity often lead to conflicts between groups that have differences from one another. Multiculturalism is an understanding that upholds the values of tolerance between groups with differing views on ethnicity, religion, culture, race, ethnicity and gender, this understanding offers equality between groups, and further promotes buman values, namely equal rights to life. One of the ways to provide multicultural understanding is through education. The results showed that Gus Dur's multiculturalism thinking included several aspects, namely, the indigenization of Islam who wanted to integrate Islam with local culture. Democracy and the enforcement of human rights is a logical consequence that is considered as one of the dimensions and an inseparable part of Islamic teachings, so that the commitment to uphold humanitarian values is obligatory. Humanism and plurality are entirely based on a deep understanding of the teachings of Islam and NU's own scientific traditions. The characteristics of Gus Dur's multiculturalism thinking are bighly anthropological theological that emphasizes social contextualism. And the results of Gus Dur's thoughts on the concept of Multicultural Islamic education include the idea of Gus Dur in an effort to display the image of Islamic education into social life is a multicultural-based Islamic education. Gus Dur believes that multicultural Islamic education can be done with various approaches and strategies. The curriculum that must be achieved in multicultural-based Islamic education must contain the universalism of Islamic teachings, humanitarian principles, the purpose of education must be emphasized more on the affective and psychomotor aspects coupled with spiritual and humanism aspects.
\end{abstract}


Application of multicultural Islamic education, so that students who study are students who have religious knowledge and have a strong general knowledge in a balanced way.

Keywords: Gus Dur, Islamic Education, Multicultural.

\begin{abstract}
Abstrak
Penelitian ini bertujuan untuk mengupas pandangan Gus Dur tentang multikulturalisme dan konsep pendidikan Islam multikultural. Penelitian ini tergolong kategori library research, karena sumber data utamanya berasal ari kajian pustaka. Data yang terkumpul selanjutnya dianalisis menggunakan teknik conten analisys dengan pendekatan deskriptif. Indonesia adalah negara yang terdiri dari berbagai suku bangsa, ras, etnis, agama, bahasa. Keberagaman tersebut menjadi suatu keunikan tersendiri yang mencirikan bangsa Indonesia, keberagaman adalah sunnatullah, akan tetapi disatu sisi keberagaman tersebut sering menimbulkan konflik antar kelompok yang memiliki perbedaan satu sama lain. Multikulturalisme adalah suatu paham yang menjunjung tinggi nilai-nilai toleransi antar kelompok yang berbeda pandangan atas suku, agama, budaya, ras, etnisdan gender, paham ini menawarkan kesederajatan antar kelompok, dan lebih mengedepankan nilai-nilai kemanusiaan, yakni persamaan hak hidup. Untuk memberikan pemahaman multikultur salah satunya yaitu melalui pendidikan. Hasil penelitian menunjukkan pemikiran multikulturalisme Gus Dur meliputi beberapa aspek yaitu, pribumisasi Islam yang ingin mengintegrasikan Islam dengan budaya lokal. Demokrasi dan penegakkan hak asasi manusia adalah konsekuensi logis yang dianggap sebagai salah satu dimensi dan bagian yang tidak terpisahkan dari ajaran Islam, sehingga komitmen untuk menjunjung tinggi nilai-nilai kemanusiaan wajib hukumnya. Humanisme dan pluralitas sepenuhnya berdasarkan pemahaman yang mendalam terhadap ajaran Islam dan juga tradisi keilmuan NU sendiri. Karakteristik pemikiran multikulturalisme Gus Dur sangatlah bersifat teologis antropologis yang mengedepankan kontekstual kemasyarakatan. Dan hasil pemikiran Gus Dur tentang konsep pendidikan Islam Multikultural meliputi gagasan Gus Dur dalam usaha menampilkan citra pendidikan Islam ke dalam kehidupan kemasyarakatan adalah pendidikan Islam berbasis multikultural. Gus Dur berpandangan pendidikan Islam multikultural itu bisa dilakukan dengan berbagai pendekatan dan beberapa strategi. Kurikulum yang harus dicapai pada pendidikan Islam berbasis multikultural harus mengandung universalisme ajaran Islam, prinsip-prinsip kemanusiaan, tujuan pendidikan harus lebih ditekankan kepada aspek afektif dan psikomotorik ditambah dengan aspek spiritual dan humanisme. Aplikasi pendidikan Islam multikultural, agar peserta didik yang belajar adalah peserta didik yang memiliki ilmu agama dan memiliki ilmu umum yang kuat secara seimbang.
\end{abstract}

Kata kunci: Gus Dur, Pendidikan Islam, Multikultural. 


\section{A. Pendahuluan}

Pendidikan merupakan suatu sarana yang sangat penting dalam menciptakan sumber daya manusia bagi masa depan bangsa. Hal ini dapat kita lihat bersama bagaimana peran pendidikan dalam membina dan membimbing generasi bangsa yang mampu bersaing dalam arus globasisasi. Oleh karena itu banyak para pakar pendidikan meneliti, dan mengembangkan pendidikan agar sesuai dengan tuntutan zaman, tak terkecuali pendidikan Islam. Keragamaan yang ada pada bangsa Indonesia di satu sisi merupakan suatu khazanah yang patut dipelihara dan memberikan dinamika bagi bangsa, namun di sisi lain dapat pula merupakan titik pangkal perselisihan dan konflik bagi masyarakat Indonesia. ${ }^{1}$

Beberapa kasus yang pernah terjadi di tanah air yang diakibatkan oleh perbedaan SARA tersebut di antaranya adalah konflik Ambon, Poso, dan konflik etnis Dayak dengan Madura di Sampit. Dari latar belakang masalah tersebut, selayaknyalah kita mengembangkan paradigma baru di dunia pendidikan, yakni paradigma pendidikan multikultural. Paradigma pendidikan multukultural tersebut pada akhirnya bermuara pada terciptanya sikap siswa atau peserta didik yang mau memahami, menghormati, menghargai perbedaan budaya, etnis, agama dan lainnya tidak menjadi penghalang bagi siswa untuk bersatu. Dengan perbedaan, siswa justru diharapkan tetap bersatu, tidak bercerai berai, mereka juga diharapkan menjalin kerja sama serta berlomba-lomba dalam kebaikan (fastabiqu al-khoiraat) di kehidupan yang sangat kompetitif. Dalam konteks pemikiran multikultural, Gus Dur tidak hanya mengadopsi cara berpikir klasik, tetapi juga berusaha mencampurkannya dengan pemikiran modern.

Dalam lingkup pendidikan agama Islam pemikiran Gus Dur bersifat statis dan menolak konsep pendidikan alternative yang ditawarkan oleh Paulo Friere yang masih bersifat politis dalam konteks konfrontatif terhadap kekuasaan sehingga berkecenderungan memberontak kepada kekuasaan yang ada dan dengan sendirinya akan membawa kepada pukulan balasan dari kekuasaan tersebut. Maka pemikiran multikultural Gus Dur tersebut patut dikembangkan dan dijadikan sebagai model pendidikan alternative di Indonesia dengan berbagai alasan, antara lain: ${ }^{2}$

${ }^{1}$ Zakiyuddin Baidhawy, Pendidikan Agama Berwawasan Multikultural (Jakarta: Erlangga, 2005), 21. ${ }^{2}$ Maslikhah, Quo Vadis Pendidikan Multikultur (Surabaya: Temprina Media Grafika, 2007), 159. 
1. Realitas bahwa Indonesia adalah negara yang dihuni oleh berbagai suku, bangsa, etnis, agama, dengan bahasa yang beragam dan membawa budaya yang heterogen serta tradisi dan peradaban yang beraneka ragam.

2. Pluralitas tersebut secara inheren sudah ada sejak bangsa Indonesia ini ada.

3. Masyarakat yang menentang pendidikan yang berorientasi bisnis, komersialisasi, dan kapitalis yang mengutamakan golongan atau orang tertentu.

4. Masyarakat tidak menghendaki kekerasan dan kesewenang-wenangan pelaksanaan hak setiap orang.

5. Pendidikan multikulturalisme sebagai resistensi fanatisme yang mengarah pada berbagai jenis kekerasan, dan kesewenang-wenangan.

6. Pendidikan multikulturalisme memberikan harapan dalam mengatasi berbagai gejolak masyarakat yang terjadi akhir-akhir ini.

7. Pendidikan multikulturalisme sangat erat dengan nilai-nilai kemanusiaan, sosial, keislaman, dan ke-Tuhanan.

Selain beberapa alasan di atas, beliau juga berpandangan bahwa multikultural dalam konteks pendidikan juga harus beragam dan sesuai dengan kulturnya masing-masing. Karena pendidikan yang beragam itu tidak menyimpang dari tujuan, melainkan suatu upaya untuk mencapai tujuan pendidikan itu sendiri melalui cara yang beragam. Dalam pandangannya yang komprehensif, beliau juga berpendapat bahwa harus ada sikap percaya diri dari individu atas kulturnya masing-masing dengan menawarkan solusi yang sering dinamakan pribumisasi Islam, yakni bagaimana mengintegrasikan Islam dengan budaya lokal, ataupun pendidikan agama Islam dengan pendidikan lokal.

Dari pengertian inilah kemudian muncul sikap inklusif, plural, dan multikultural terhadap individu. Sikap yang demikian merupakan solusi dalam mewujudan masyarakat Indonesia yang multikultural, sehingga tindakan rasisme, separatis, maupun konflik-konflik lainnya tidak akan terjadi lagi. ${ }^{3}$ Berdasarkan latar belakang dan batasan masalah yang peneliti tentukan, maka permasalahan ini difokuskan pada: Bagaimana pemikiran Gus Dur tentang multikulturalisme? Bagaimana pemikiran Gus Dur tentang konsep pendidikan Islam multikultural?

\footnotetext{
${ }^{3}$ Abdurrahman Wahid, Islamku Islam Anda Islam Kita (Jakarta: The Wahid Institute, 2006), 223.
} 


\section{B. Hasil dan Pembahasan}

\section{Pendidikan Islam Multikultural}

Pendidikan Islam multikultural menggunakan seperangkat metodologi keilmuan yang dapat membantu seorang memahami pengetahuan secara komprehensif, yakni hermeneutika. Tujuan pendidikan Islam multikultural adalah menciptakan masyarakat madani yang menjunjung tinggi konsep social contract, yaitu sebuah konsep yang setiap individu dan kelompok memiliki hak dan kewajiban yang sama, meskipun mereka berada di bawah latar belakang yang berbeda. Karakteristik pendidikan multikultural tersebut antara lain: Pertama, pendidikan yang berprinsip pada demokrasi, kesetaraan dan keadilan. Kedua, prinsip demokrasi, kesetaraan dan keadilan merupakan prinsip yang mendasari pendidikan multikultural, baik pada level ide, proses, maupun gerakan. Pendidikan yang berorientasi kepada kemanusiaan, kebersamaan dan kedamaian untuk mengembangkan prinsip demokrasi, kesetaraan dan keadilan dalam kehidupan bermasyarakat, terutama di masyarakat yang heterogen, diperlukan orientasi hidup yang universal adalah kemanusiaan, kebersamaan, dan kedamaian. Orientasi hidup yang universal ini merupakan titik orientasi bagi pendidikan multikultural.

Dari aspek didaktif, kurikulum merupakan salah satu aspek yang penting dalam pendidikan multikultural. Lebih jauh tentang pendidikan multikultural ini, Mark K. Smith memposisikan kurikulum pada empat pendekatan, yaitu: (1) Kurikulum sebagai silabus (curriculum as a body of knowledge to be transmited). (2) Kurikulum sebagai produk (curriculum as product). (3) Kurikulum sebagai proses (curriculum as proses). (4) Kurikulum sebagai praksis (curriculum as praxis). ${ }^{4}$ Untuk memberikan pendidikan multikultural, sekolah atau guru perlu menelaah secara kritis tentang materi dan bahan ajar yang akan disampaikan dalam proses pembelajaran, agar tidak terjadi berbagai macam bias.

\section{Pemikiran Multikulturalisme Gus Dur}

Ada dua tulisan Gus Dur yang berkaitan langsung dengan tema pribumisasi Islam. Pertama, artikel "Salahkah jika dipribumikan" yang berbentuk tulisan kolom di majalah Tempo pada 16 juli 1983, dan kedua, "Pribumisasi Islam", sebuah antologi dalam Muntaha Azhari dan Abdul Mun'im Saleh. Gagasan "pribumisasi Islam"

${ }^{4}$ Rijal Firdaos, "Orientasi Pedagogik dan Perubahan Sosial Budaya Terhadap Kemajuan Ilmu Pendidikan dan Teknologi," Al-Tadzkiyah, 6 (Mei 2015), 115. 
dimaksudkan Gus Dur sebagai jawaban atas problem yang dihadapi umat Islam sepanjang sejarahnya, yakni bagaimana mempertemukan budaya ('adah) dengan norma (syari'ah), sebagaimana juga menjadi persoalan dalam usul al-figh. Menurut Gus Dur, tumpang tindih antara agama dan budaya akan terjadi terus menerus sebagai suatu proses yang akan memperkaya kehidupan dan akan membuatnya tidak gersang. ${ }^{5}$ Agama Islam dan budaya mempunyai independensi masing-masing, tetapi keduanya memang mempunyai wilayah tumpang tindih, sebagaimana filsafat dan ilmu pengetahuan. Seseorang tidak akan bisa berfilsafat tanpa ilmu pengetahuan, tetapi juga tidak bisa dikatakan bahwa ilmu pengetahuan adalah filsafat. Di antara keduanya agama dan budaya terjadi tumpang tindih dan sekaligus beda.

Bagi Gus Dur, Islam berfungsi penuh dalam kehidupan sebuah masyarakat bangsa melalui pengembangan nilai. Pengembangan nilai-nilai dasarnya sebagai etika masyarakat yang bersangkutan. Islam berfungsi bagi kehidupan masyarakat bangsa tidak sebagai untuk kenegaraan tertentu, tetapi sebagai etika sosial yang akan memandu jalannya kehidupan bernegara dan bermasyarakat itu, sesuai dengan martabat luhur dan kemulian derajat manusia. Karena pada analisis terakhir, manusialah yang menjadi objek upaya penyejahteraan hidup itu.

Terkait dengan apa yang selama ini menjadi perdebatan mengenai ideologi negara, dikatakan: "Kita tidak usah mencari-cari negara yang ideal karena memang tidak ada yang ideal. Islam tidak menyebutkan tentang soal negara ideal, dan juga tidak mengharuskan. Allah meridai Islam sebagai agamamu, bukan sebagai sistem pemerintahan. Islam menjadi besar kalau ia tidak menampakkan wajah politik melainkan mengutamakan wajah moralnya, atau dengan kata lain Islam mengutamakan politik sebagai institusi. Menurut pengakuannya, Saya lebih melihat kepada pencapaian cita-cita Islam yang sebenarnya, yakni keadilan, kemakmuran dan kesamaan di antara semua umat manusia. Kalau kita masih menginginkan bahwa Islam harus lebih dari yang lain, itu tidaklah islami. Justru bertentangan dengan Islam". ${ }^{6}$

\footnotetext{
${ }^{5}$ Tim INCReS, Beyond the Symbols: Jejak Antropologis Pemikiran dan Gerakan Gus Dur (Bandung: PT. Remaja Rosdakarya, 2000), 43.

${ }^{6}$ Rijal Firdaos, "Orientasi Pedagogik dan Perubahan Sosial Budaya Terhadap Kemajuan Ilmu Pendidikan dan Teknologi"
} 
Ada dua hal penting yang harus diperhatikan berkenaan dengan sikap dilogis yang ditujukan pada dua cabang dalam kehidupan agama. Pertama, Gus Dur sendiri berpendapat bahwa perbedaan agama-agama cenderung merupakan perbedaan yang berada dalam tataran kemanusiaan. Dia mengatakan bahwa sesungguhnya yang menjadi hakim untuk mengatakan seseorang masuk surge dan neraka. ${ }^{7}$ Kedua, Gus Dur juga melangkah pada segi-segi yang lebih praktis. Bagi Gus Dur, praktis agama menjadi sesuatu yang sangat esensial di dalam hubungan antar agama yang didasari oleh toleransi dan langkah yang sangat konkrit. Sebagai bukti, Gus Dur melakukan kerjasama dengan siapa saja secara terbuka, baik dalam kelompok Kristen, Hindu, Budha, maupun kelompok Islam yang lain. Meski kemudian banyak berhubungan dengan kelompok-kelompok sekuler yang tidak terlalu banyak mempersoalkan doktrindoktin atau dogma-dogma agama adalah perkembangan lain. ${ }^{8}$

Tulisan Gus Dur berjudul Pengembangan Fiqih Secara Kontekstual dipaparkan bahwa ideologi multikulturalisme yang dibawa beliau dan penghormatannya terhadap pluralitas sepenuhnya berdasarkan pemahaman yang medalam terhadap ajaran Islam dan juga tradisi keilmuan NU sendiri. Pertama, prinsip multikulturalisme secara tegas diakui di dalam kitab suci Al-Qur'an secara tegas mendeklarasikan bahwa pluralitas masyarakat dari segi agama, etnis, warna kulit, bangsa, dan sebagainya merupakan keharusan sejarah yang menjadi kehendak Allah, Karena itu upaya penyeragaman dan berbagai bentuk hegemonisasi yang lain, termasuk dalam hal pemahaman dan implikasi ajaran agama merupakan sesuatu bertentangan dengan semangat dasar al-Quran.

Beberapa pemikiran Gus Dur, menggambarkan bahwa Gus Dur bukanlah seorang yang eksistensialis, melainkan seorang yang beragama dan percaya pada konsep wahyu, tetapi Gus Dur gabungkan dengan pemikiran modern. Ini adalah sumber multikulturalisme intelektual, tetapi ada juga sumber-sumber multikultural yang lain. Orang bisa pluralis karena punya sikap humanitarian, kecintaan terhadap manusia membuat kita saling menghormati.

${ }^{7}$ Tim INCReS, Beyond The Symbls: Jejak Antropologis Pemikiran dan Gerakan Gus Dur, 108. ${ }^{8}$ Tim INCReS, Beyond The Symbls: Jejak Antropologis Pemikiran dan Gerakan Gus Dur, 109. 


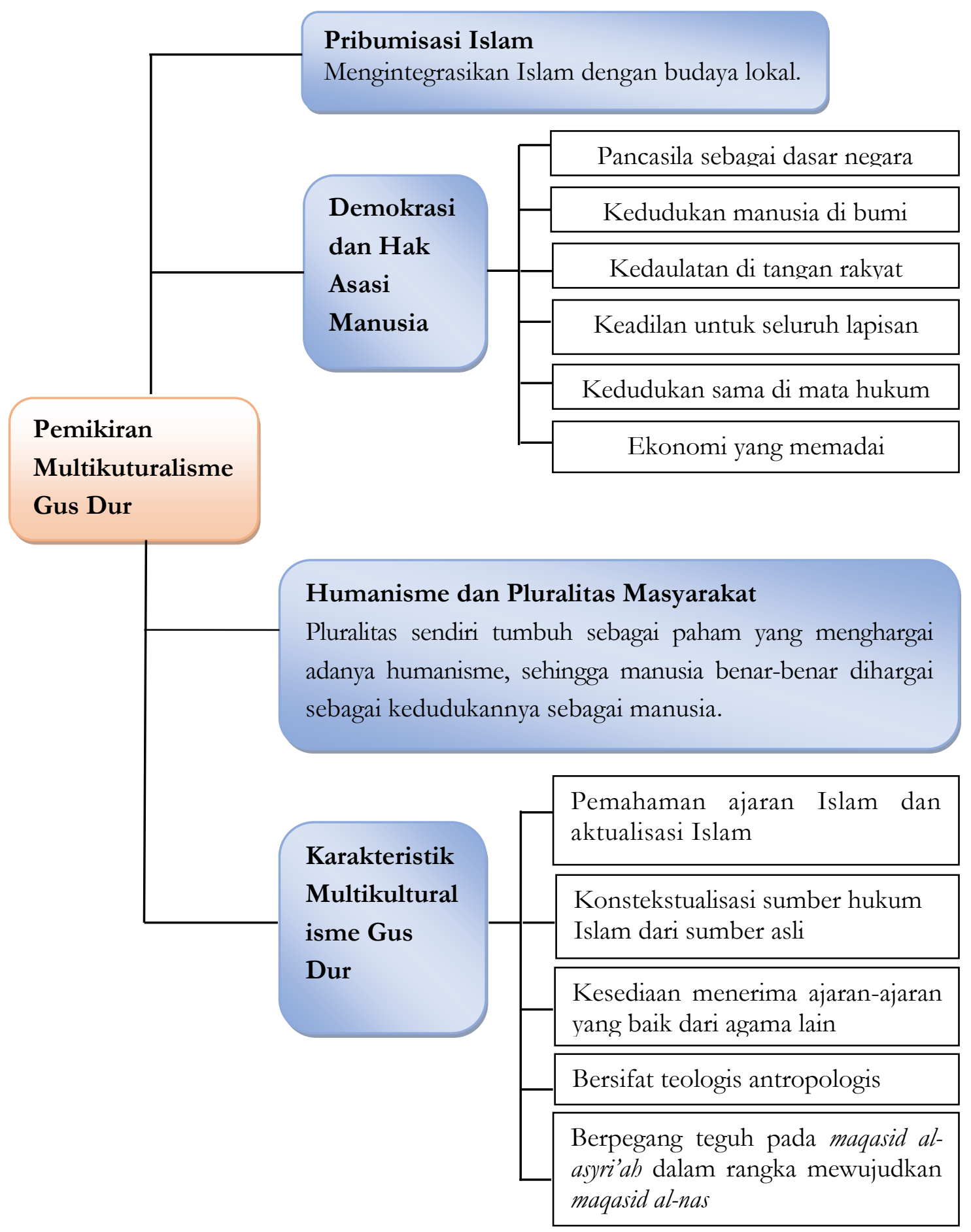

Gambar 1 Pemikiran Multikulturalisme Gus Dur 


\section{Pemikiran Gus Dur Tentang Konsep Pendidikan Islam Multikultural}

Salah satu gagasan Gus Dur dalam usaha menampilkan citra pendidikan Islam ke dalam kehidupan kemasyarakatan adalah pendidikan Islam berbasis multikultural. Pendidikan ini mengutamakan sikap mengembangkan pandangan dan perangkat kultural yang dilengkapi oleh upaya membangun system kemasyarakatan yang sesuai dengan wawasan budaya yang ingin dicapai itu. Pendidikan ini lebih mementingkan aktivitas budaya dalam konteks pengembangan lembaga-lembaga yang dapat mendorong transformasi sistem sosial secara evolutif. Hal ini dapat mempermudah dalam menggagas pendidikan Islam berbasis multikultural sebagaimana ciri khas pendidikan tersebut.

Gus Dur berpandangan pendidikan Islam multikultural itu bisa dilakukan dengan berbagai pendekatan dan strategi, misalnya dengan cara pembaharuan pendidikan Islam dan modernisasi Gus Dur memberi contoh yaitu penggunaan tutup kepala di sekolah non-agama, yang di negeri ini dikenal dengan nama jilbab. KeIslaman lahiriyah seperti itu, juga terbukti dari semakin tingginya jumlah mereka dari tahun ke-tahun yang melakukan ibadah umroh atau haji kecil. Demikian juga, semangat menjalankan ajaran Islam datangnya lebih banyak dari komunikasi di luar sekolah, antara Berbagai komponen masyarakat Islam. Dengan kata lain, pendidikan Islam tidak hanya disampaikan dalam ajaran-ajaran formal Islam di sekolah-sekolah agama atau madrasah belaka, melainkan juga melalui sekolah-sekolah non-agama yang berserakserak di seluruh penjuru dunia. ${ }^{?}$

Kemudian beberapa strategi yang ditawarkan Gus Dur Terkait dengan pendidikan dapat penulis himpun sebagai berikut:

a. Strategi Sosio-Politik

Strategi ini menekankan pentingnya formalisasi ajaran-ajaran Islam ke dalam lembaga-lembaga negara melalui upaya formal dan legal. Untuk menerapkan hal tersebut pendidikan Islam harus menekankan aspek etika dalam lembaga, SDM, masyarakatnya.

b. Strategi Kultural

\footnotetext{
${ }^{9}$ Abdurrahman Wahid, Islamku Islam Anda Islam Kita, 225.
} 
Strategi ini dirancang untuk mengembangkan pendidikan Islam dengan memperbaharui kualitas pendidikan tersebut agar selaras dengan jaman. Tujuan ini dapat dicapai dengan memperdalam kesadaran pendidikan islam mengenai kompleksitas lingkunganya. Kemudian pendidikan islam terutama pesantren harus menekankan berfikir rasionalis dan dan memperkuat solidaritas terhadap sesama umat manusia tanpa memandang ideologi, asal-usul, ras, atau budaya. Strategi sosiokultural

Pendidikan Islam lebih bisa diterima masyarakat melalui lembaga-lembaga umum. Gus Dur menempatkan pesantren pada sebuah tempat eksklusif dalam transformasi ajaran Islam. Pemikiran-pemikiran Gus Dur masih terbuka dalam memperjuangkan budaya-budaya Islam tradisional, khususnya budaya pesantren, namun tidak menutup mata terhadap kondisi dan perkembangan zaman yang terus berevolusi.

c. Strategi pedagogis

Titik tekan terhadap keberhasilan penerapan pendidikan Islam multikultural mengarah pada pendidik yang yang berkompeten, profesional, berwawasan luas, serta karismatik. Karismatik menurut Gus Dur Ialah nilai lebih dalam membangun spiritualitas antara pendidik dengan peserta didik di samping pendidik juga memiliki wawasan luas tentang harmonisasi dan humanisasi yang tinggi dalam menciptakan pendidikan yang multikultural. Menurut Ngainun Naim dan Achmad Syauqi penanaman nilai-nilai spiritual dan kultur sejak dini merupakan langkah yang paling efektif dalam membentuk karakter peserta didik di masa depan. ${ }^{10}$

\section{Kurikulum Pendidikan Islam Multikultural}

Universalisme Islam menurut Gus Dur termanifestasikan dalam rangkaian ilmu pengetahuan yang biasa disebut pondasi agama Islam. ilmu hukum (fiqh), keimanan (taubid), serta etika (akblaq). Universalisme dalam pendidikan Islam tersebut selanjutnya harus mengandung prinsip-prinsip kemanusiaan. Prinsip-prinsip kemanusiaan itu menurut Gus Dur adalah sebagai jalan diterimanya pendidikan Islam sebagai pendidikan yang humanis. Prinsip-prinsip tersebut telah dirumuskan dalam literatur

${ }^{10}$ Ngainun Na'im dan Ahmad Syauqi, Pendidikan Multikultural: Konsep dan Aplikasi (Yogyakarta: ArRuuz Media, 2010), 34. 
kuno yaitu: pertama, keselamatan lahiriah manusia di luar ketentuan hukum (bifdzu nafs). Kedua, jaminan kebebasan berkeyakinan tanpa ada paksaan untuk berpindah keyakinan (bifdzu ad-din). Ketiga, jaminan keselamatan keluarga dan keturunan (bifdzu an-nasl). Keempat, jaminan keselamatan harta benda dan kepemilikan di luar ketentuan hukum (bifdzu al-mal), Jaminan ini menampilkan sosok lain dari universalisme Islam, kebebasan profesi berarti kebebasan untuk melakukan pilihan atas resiko masing-masing akan keberhasilan yang ingin diraih. Kebebasan yang telah diraih merupakan penentuan arah hidup dan tanggung jawabnya sendiri. ${ }^{11}$

\section{Aplikasi Pendidikan Islam Multikultural}

Pesantren sebagai salah satu lembaga yang bernafaskan Islam memiliki keunikan tersendiri. Aplikasi pendidikan islam multikultural yang digagas Gus Dur tidak lepas dari lembaga pendidikan Islam tersebut. Sebagaimana yang telah dibahas di atas, kita melihat paling kurang terdapat lima macam tipologi pesantren. Pertama, lembaga pendidikan pesantren yang bersifat salafi, yaitu lembaga pendidikan pesantren yang hanya mengajarkan agama dengan bersandar pada kitab-kitab klasik dengan menggunakan sistem halaqah, sorogan dan bandongan. Kedua, lembaga pendidikan pesantren yang selain memiliki ciri-ciri pesantren salafi sebagai mana tersebut di atas, juga telah mengadopsi sistem madrasah, walaupun muatan kurikulumnya sepenuhnya agama. Ketiga, lembaga pendidikan pesantren yang selain memiliki sistem madrasah juga sudah melengkapinya dengan sistem sekolah umum yang memungkinkan santrinya dapat melanjutkan ke tingkat pendidikan yang lebih tinggi baik di perguruan tinggi agama maupun pada perguruan tinggi umum. Keempat, sistem pendidikan pesantren yang sudah melengkapi dirinya dengan keunggulan dalam menguasai bahasa asing dan teknologi modern. Kelima, sistem pendidikan pesantren yang santrinya diarahkan untuk menjadi tenaga kerja professional yang dibutuhkan masyarakat. Pada pesantren model kelima ini, para lulusannya diarahkan untuk bekerja secara mandiri pada sektor informal. $^{12}$

\footnotetext{
${ }^{11}$ Abdurrahman Wahid, Islam Kosmopolitan, 148-149.

${ }^{12}$ Abudin Nata, Tokoh-Tokoh Pembaharuan Pendidikan Islam di Indonesia (Jakarta: PT Raja Grafindo Persada, 2005), 353.
} 
Munculnya dinamika pesantren yang demikian itu tidak lepas dari gagasan Gus Dur menginginkan terjadinya proses penggalakan kembali nilai-nilai lama yang tidak relevan lagi dengan nilai-nilai baru yang lebih relevan dan dianggap baik dan lebih sempurna. Inilah yang selanjutnya memunculkan istilah yang berbunyi: al-muhafadzah ala al-qadim al-shalih wal al-akbdzu bi al-jadid al-ashlah (memelihara dan melestarikan nilainilai lama yang masih relevan dan mengambil nilai-nilai baru yang lebih relevan lagi.

Gus Dur berpendapat bahwa lembaga pendidikan Islam perlu menyelenggarakan kajian pendidikan umum. Alasan tersebut antara lain: Pertama, bahwa mayoritas masyarakat tidak semua belajar di lembaga pendidikan Islam. Kedua, masyarakat yang belajar di sekolah umum dengan belajar agama di lembaga Islam, akan terdorong untuk memasuki pendidikan Islam dan sekaligus memasuki lembaganya. Dalam konteksnya Gus Dur tidak menginginkan adanya dikotomi pendidikan. Semua aspek-aspek pendidikan hendaknya bersaing secara sehat dalam mencapai tujuan dan karakter masing-masing.

Berdasarkan pada gagasannya, Gus Dur menginginkan juga agar peserta didik yang belajar adalah peserta didik yang memiliki ilmu agama yang kuat sekaligus juga memiliki ilmu umum yang kuat secara seimbang. Gus Dur menginginkan, agar di samping mencetak ahli ilmu agama Islam, juga mampu mencetak orang yang memiliki keahlian dalam ilmu pengetahuan dan teknologi, seperti ilmu komputer, fisika, pertanian, perkebunan, dan sebagainya. Tetapi yang patut digaris bawahi peserta didik tersebut mampu menjadi peserta didik yang humanis terhadap peserta didik lainnya sebagai bekal kehidupan bermasyarakat.

Selanjutnya Gus Dur juga menginginkan agar kurikulum pendidikan Islam memiliki keterkaitan dengan kebutuhan lapangan kerja. Untuk kalangan dunia kerja, baik dalam bidang jasa maupun dalam bidang perdagangan dan keahlian lainnya, pendidikan Islam harus memberikan masukan bagi kalangan pendidikan lainya, tentang keahlian apa yang sesungguhnya dibutuhkan oleh lapangan kerja yang di era globalisasi seperti sekarang ini demikian cepat dan beragam. Menurut Gus Dur, tujuan pendidikan Islam bukan hanya terletak pada upaya tafaqquh fi aI-din, yakni menghasilkan manusia yang mendalami ilmu agama setingkat ulama, melainkan terintegrasinya pengetahuan 
agama dan non-agama, sehingga lulusan yang dihasilkan pesantren adalah suatu kepribadian yang utuh dan bulat dalam dirinya, yakni pribadi yang di dalamnya tergabung unsur-unsur keimanan yang kuat atas pengetahuan secara seimbang. Peserta didik yang dihasilkan pendidikan yang demikian itu, sebagai peserta didik yang memiliki wawasan pemikiran yang luas, pandangan hidup yang matang dan mampu melakukan kerja-kerja praktis, serta berwatak multi sektoral dalam memecahkan persoalanpersoalan yang dihadapinya. Dengan kata lain, peserta didik yang mampu memandang jauh ke depan, di samping memiliki keterampilan praktis untuk menyelesaikan berbagai persoalannya sendiri secara tuntas. ${ }^{13}$

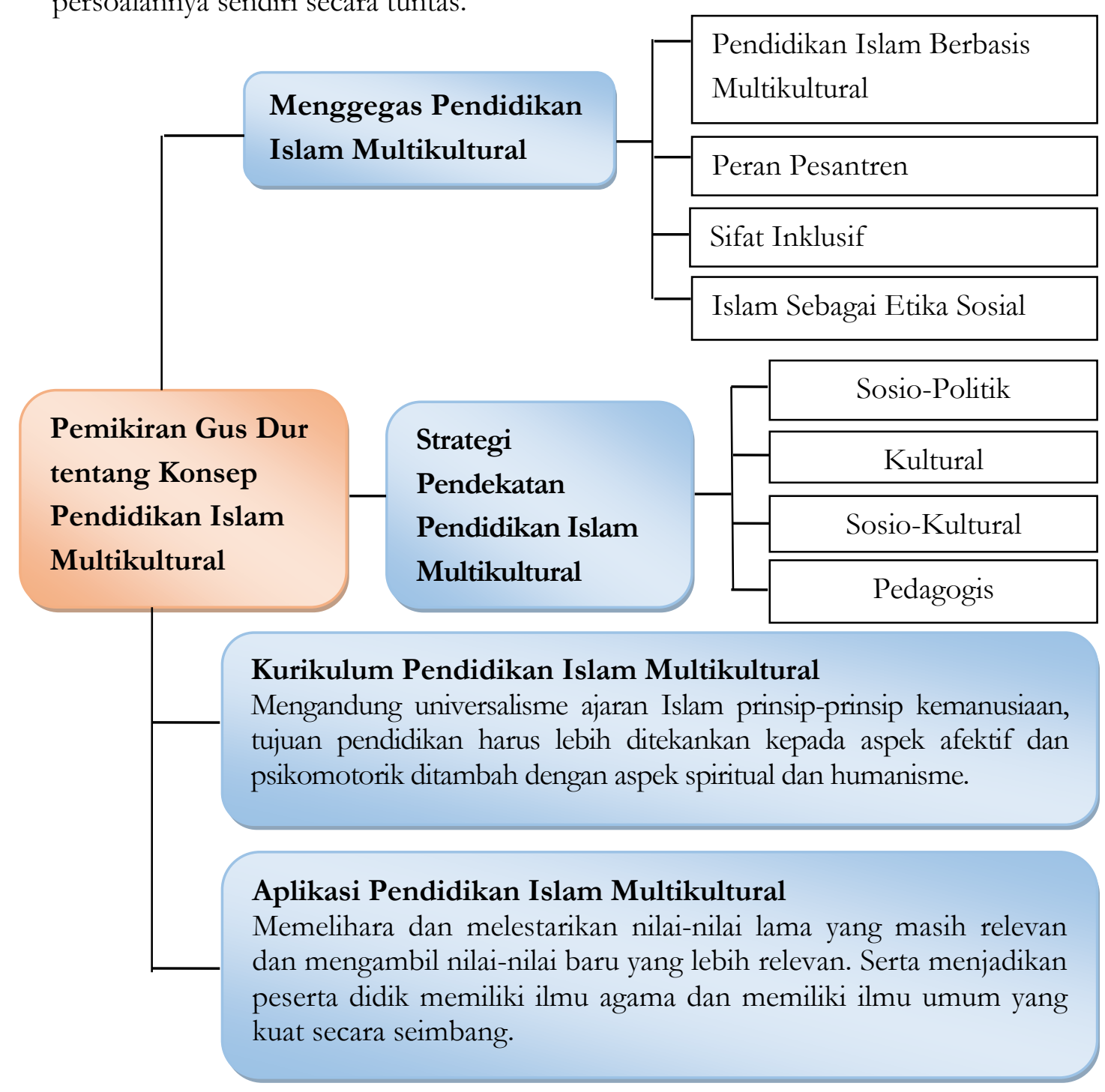

\footnotetext{
${ }^{13}$ Abudin Nata, Tokoh-Tokoh Pembaharuan Pendidikan Islam di Indonesia
} 
Gambar 2 Pemikiran Gus Dur Tentang Konsep Pendidikan Islam Multikultural

\section{Simpulan}

Dari hasil penelitian maka dapat diambil kesimpulan, pemikiran Multikulturalisme Gus Dur, Menurut Gus Dur pribumisasi Islam adalah suatu pemahaman yang mempertimbangkan kebutuhan-kebutuhan lokal didalam merumuskan hukum-hukum agama tanpa mengubah hukum itu sendiri. Jadi pribumisasi Islam bukan suatu upaya meninggalkan norma demi budaya, tetapi agar norma-norma itu menampung kebutuhan-kebutuhan dari budaya dengan mempergunakan peluang yang disediakan oleh variasi pemahaman nash, dengan tetap memberikan peranan kepada usul al-fiqh dan qawaiid al-figh. Demokrasi merupakan salah satu tema besar yang perlu digaris bawahi dari perjuangan dan pemikiran Gus Dur. Baginya konsep demokrasi adalah konsekuensi logis yang dianggap sebagai salah satu dimensi dalam ajaran Islam. Ideologi pemikiran Gus Dur dan penghormatannya terhadap humanisme dan pluralitas sepenuhnya berdasarkan pemahaman yang mendalam terhadap ajaran Islam dan juga tradisi keilmuan NU sendiri yang mengikuti tradisi pemikiran madzhab yang menjadi pilar tegaknya peradaban fiqih. Karakteristik pemikiran multikulturalisme Gus Dur sangatlah bersifat teologis antropologis yang mengedepankan kontekstual kemasyarakatan.

Pemikiran Gus Dur Konsep Pendidikan Islam Multikultural Gagasan Gus Dur dalam usaha menampilkan citra pendidikan Islam ke dalam kehidupan kemasyarakatan adalah pendidikan Islam berbasis multikultural. Gus Dur berpandangan pendidikan Islam multikultural itu bisa dilakukan dengan berbagai pendekatan dan strategi, misalnya dengan cara pembaharuan pendidikan Islam dan modernisasi pendidikan Islam. Strategi yang ditawarkan Gus Dur adalah strategi sosio-politik, strategi ini menekankan pentingnya formalisasi ajaran-ajaran Islam ke dalam lembaga-lembaga negara melalui upaya formal dan legal. Strategi kultural, strategi ini dirancang untuk mengembangkan pendidikan Islam dengan memperbaharui kualitas pendidikan tersebut agar selaras dengan jaman. Strategi sosio-kultural, strategi ini menekankan bahwa pendidikan Islam perlu mengembangkan nilai-nilai keislaman yang tidak harus dilembagakan. Artinya pendidikan Islam lebih bisa diterima masyarakat melalui lembaga-lembaga umum. Strategi pedagogis, titik tekan 
terhadap keberhasilan penerapan pendidikan Islam multikultural mengarah pada pendidik yang yang berkompeten, profesional, berwawasan luas, serta karismatik.

Menurut Gus Dur kurikulum yang harus dicapai pada pendidikan Islam berbasis multikultural harus mengandung universalisme ajaran Islam itu sendiri. Aplikasi pendidikan Islam multikultural, Gus Dur menginginkan agar peserta didik yang belajar adalah peserta didik yang memiliki ilmu agama dan memiliki ilmu umum yang kuat secara seimbang. Gus Dur menginginkan, agar di samping mencetak ahli ilmu agama Islam, juga mampu mencetak orang yang memiliki keahlian dalam ilmu pengetahuan dan teknologi, seperti ilmu komputer, fisika, pertanian, perkebunan, dan sebagainya. Tetapi yang patut digaris bawahi peserta didik tersebut mampu menjadi peserta didik yang humanis terhadap peserta didik lainnya sebagai bekal kehidupan bermasyarakat.

\section{Daftar Pustaka}

Al-Rasheed, Momoon. Islam Tanpa Kekerasan. Yogyakarta: LkiS, 1998

Arikunto, Suharsimi. Prosedur Penelitian Suatu Pendekatan Praktek. Jakarta: PT Rineka Cipta, 2006.

Azra, Azyumardi. Pendidikan Islam Tradisional dan Modernitas Menuju Milenium Baru. Ciputat: Logos Wacana Ilmu, 2002.

Baidhawy, Zakiyuddin. Pendidikan Agama yang Berwawasan Multikultural. Jakarta: Erlangga, 2005.

Barton, Greg. Biografi Gus Dur The Authorized Biography of Abdurrahman Wahid. Yogyakarta: Saufa, 2016.

Gagasan Islam Liberal di Indonesia. Jakarta: Paramadina, 1999.

Baso, Ahmad. "Islam Liberal sebagai Ideologi Nurcholis Madjid Versus Abdurrahman Wahid." Gerbang Vol 6, No. 3 (Februari-April 2000).

Dhakiri, Hanif. Warisan Kebesaran Gus Dur. Yogyakarta: LKIS, 2010.

Faisol. Gus Dur dan Pendidikan Islam. Yogyakarta: Arruz Media, 2011.

Firdaos, Rijal. "Orientasi Pedagogik dan Perubahan Sosial Budaya Terhadap Kemajuan Ilmu Pendidikan dan Teknologi." Al-Tadzkiyah Vol 6. 2015.

Fitriah, Ainun. "Pemikiran Abdurrahman Wahid Tentang Pribumisasi Islam." Jurnal Teosofi Vol 3, No 1 (Juni 2013).

Fuad, Ismail.“Konsep Pendidikan Multikultural dalam Pendidikan Islam.” Skripsi. Fakultas Ilmu Tarbiyah dan Keguruan, UIN Syarif Hidayatullah, 2009.

Hanif, M. Dhakiri. 41 Warisan Kebesaran Gus Dur. Yogyakarta: LkiS, 2010. 
Hidayat Rifa'i, Mukhlis. "Pendidikan Agama Islam Multikultural Telaah terhadap Buku Pendidikan Agama Berwawasan Multikultural Karya Zakiyuddin Bidhawy." Skripsi. Fakultas Tarbiyah, UIN Sunan Kalijaga Yogyakarta, 2009.

INCReS, Tim. Beyond the Symbols: Jejak. Antropologis Pemikiran dan Gerakan Gus Dur. Bandung: PT. Remaja Rosdakarya, 2000.

Mahfud, Choirul. Pendidikan Multikultural. Yogyakarta: Pustaka Pelajar, 2016.

Mardalis. Metode Penelitian: Pendekatan Proposal. Jakarta: Bumi Aksara, 1999.

Maslikhah. Quo V adis Pendidikan Multikultur. Surabaya: Temprina Media Grafika, 2007.

Miskan. "Pemikiran KH. Abdul Rahman Wahid (Gus Dur) tentang Multikulturalisme dan Implikasinya terhadap Pendidikan Agama Islam di indonesia." Tesis. Fakultas Ilmu Tarbiyah dan Keguruan, UIN Sunan Kalijaga, 2017.

Mubarok Yasin, Ahmad. Gus Dur Di Mata Keluarga dan Sababat. Jombang: Pustaka Tebuireng, 2010.

Mujib, Abdul dan Jusuf Mudzakkir. Ilmu Pendidikan Islam. Jakara: Kencana Prenada Media, 2010.

Mustamar, Marzuki. Dalil-Dalil Praktis Amaliah Nahdliyah. Surabaya: Muara Progresif, 2016.

Na'im, Ngainun dan Ahmad Syauqi. Pendidikan Multikultural: Konsep dan Aplikasi. Yogyakarta: Ar-Ruuz Media, 2010.

Nata, Abudin. Metodologi Studi Islam. Jakarta: Rajawali Pers, 2013.

-. Tokoh-Tokoh Pembaharuan Pendidikan Islam di Indonesia. Jakarta: Raja Grafindo Persada, 2005.

Nazir, Muhammad. Metode Penelitian. Jakarta: Galia Indonesia, 1988.

Ramayulis. Ilmu Pendidikan Islam. Jakarta: Kalam Mulia, 2013.

Rifa'I, Muhammad. Gus Dur: KH. Abdurrahman Wabid Biografi Singkat 1940-2009. Yogyakarta: Garasi House of Book, 2010.

Rodli, A.F dan Salim F. Berguru kepada Bapak Bangsa: Kumpulan Esai Menelusuri Jejak Pemikiran KH. Abdurrabman Wabid. Jakarta: PP Gerakan Pemuda Anshor, 1999.

Rois, Achmad. "Pendidikan Islam Multikultural: Telaah Pemikiran Muhammad Amiin Abdullah." Jurnal Episteme Vol 8. No 2 (2013).

Sahal, Akhmad. Islam Nusantara. Bandung: Mizan, 2016.

Sanusi, Ahmad dan Sohari. Ushul Fiqh. Jakarta: Rajawali Pers, 2015

Suaedy, Ahmad dan Raja Juli Antoni. Para Pembaharu Pemikiran dan Gerakan Islam Asia Tenggara. Jakarta: SEAMUS, 2009.

Sudiyono, M. Ilmu Pendidikan Islam. Jakarta: Rineka Cipta, 2009.

Sunarto. "Sistem Pembelajaran PAI Berwawasan Multikultural." Al-Tadzkiyah Vol 8, No. 2 (2017). 
Suryana, Yaya dan Ahmad Rusdiana.. Pendidikan Multikultural (Suatu Upaya Pengutan Jati Diri Bangsa. Bandung: Pustaka Setia, 2015.

Susanto, Edi. "Multikulturalisme Pendidikan Agama Islam: Telaah atas Pemikiran Nurcholish Madjid.” Jurnal Tadris Vol 2, No 2 (2007).

Suyoto, Agus. Atlas W ali Songo. Depok: Pustaka IIMan, 2016.

Wahid, Abdurrahman. Tabayun Gus Dur. Yogyakarta: Lkis, 1998. 